\title{
Determinants of Bid-Ask Spread in Indonesia: More Evidence from LQ45 Index
}

\author{
Herma Wiharno \\ Universitas Kuningan \\ wiharnoherma@yahoo.co.id \\ Dede Sri Rahayu \\ Universitas Kuningan \\ rahayudedesri9@gmail.com
}

\begin{abstract}
The investors are one of the important components of the capital market. The investors are the person who invests money in the company. In the capital market, the investors are helped by a broker. The broker helps the investors in overcoming the mismatch between price and quantity that is not in line with expectations. When an investor wants to buy a stock, the broker will ask the asking price and if an investor wants to sell investor's shares, the broker will provide the bid price. The difference between the bid price and the asking price is called bid-ask spread. Bid-ask spread is the compensation given to the market maker for the services provided. There are several factors that affect the bidask spreads that are trading volume, variance return, market value, and return on equity. This study aimed to provide empirical evidence of the effect of trading volume activity, variance return, market value, and return equity on companies listed in the LQ45 index period of 2013-2016. The sample in this research used purposive sampling. The analysis method for this research was multiple regression models. The results of this research showed that trading volume activity, variance return, market value, and return on equity simultaneously influence bid-ask spread. Partially, trading volume activity has negative insignificantly effect on bid-ask spread. The independence of the board of commissioners has negative insignificantly effect on bid-ask spread. Variance return, market value, return on equity, and have a positive significant effect on bid-ask spread.
\end{abstract}

Keywords: trading volume activity, variance return, market value, return on equity, bid-ask spread.

JEL Classification: F30, G14, G15

\section{INTRODUCTION}

\section{Background}

The capital market activity in Indonesia has existed since 1912. The capital market is a means to bring together between parties who have

funds with parties who need funds by way of trading securities. Stock exchanges are the place for 
purchasing the securities (Tandelilin, 2010).

One of the securities traded in the stock exchanges is share. Shares are a proof of equity ownership of the capital/funds in a company (Fahmi, 2015). The companies that are listed on the Indonesia Stock Exchange are grouped into 9 industry-based sectors determined by the Indonesia Stock Exchange. In addition to being grouped into sectors, these companies are also grouped into various indexes. One of the examples of indices in the Indonesian the capital market is the LQ45 index. The LQ45 index represents 45 issuers with high liquidity selected through several selection criteria.

Many parties play a role in the stock exchange. One of the parties in the stock market is an investor. Investors will need to have information and knowledge related to stock prices and other considerations to make decisions about which stocks to choose from. It aims to minimize the uncertainty of the level of risk that occurs as well as help investors get the expected profit levels. Brokers are parties who can assist in the implementation of stock trading transactions and provide information needed to investors. When an investor wants to buy a stock, the broker will ask the asking price and if an investor wants to sell the stock, the broker will provide the bid price. The difference between the bid price and the asking price is called bid-ask spread. Conceptually, bid-ask spread is the compensation given to the market maker for its services (Megginson, 1997 and Callahan et al., 1997). The market must provide a reasonable spread so that investors are not burdened by the costs incurred due to share ownership. Therefore, reasonable spreads are no more equal to average (George and Longstaff, 1993). Bid-ask spread is influenced by several factors.

The research conducted by Surya (2016: 12) stated that stock price had a significant negative effect to bid-ask spread, trading volume did not affect bid-ask spread, market value had a significant positive effect to bid-ask spread, variance return had a significant effect of the bid-ask spread. The research conducted by Widhyawati and Damayanthi (2015: 774) stated that trading volume had a negative effect on bid-ask spread, market value negatively affects bid-ask spread, and variance return had no effect on bid-ask spread on stock split - The research conducted by Tengko et al.(2014: 674) stated that Return on Equity (ROE) significantly influences bid-ask spread on bullish market trend. Raharjo (2014: 91) stated that the influential of independent variable the independence of the board of commissioners is negative significantly. 
Table 1. Bid-ask Spread Companies which are included in the LQ45 Index for the Period 2013-2016 (in base points)

\begin{tabular}{|r|l|r|r|r|r|}
\hline No. & \multicolumn{1}{|c|}{ Sectors } & 2013 & 2014 & 2015 & 2016 \\
\hline 1. & Various industry sectors & 175 & 72 & 55 & 50 \\
\hline 2. & Consumer goods industry sector & 87 & 54 & 51 & 59 \\
\hline 3. & Basic industrial and chemical sector & 94 & 72 & 51 & 49 \\
\hline 4. & $\begin{array}{l}\text { Infrastructure, utilities and transportation } \\
\text { sector }\end{array}$ & 114 & 50 & 47 & 40 \\
\hline 5. & Financial sector & 86 & 43 & 49 & 38 \\
\hline 6. & Trade, services and investment sectors & 226 & 73 & 61 & 73 \\
\hline 7. & Mining Sector & 153 & 16 & 83 & 41 \\
\hline 8. & Agricultural sector & 104 & 38 & 67 & 75 \\
\hline 9. & $\begin{array}{l}\text { Property sector, real estate, and building } \\
\text { construction }\end{array}$ & 113 & 49 & 47 & 51 \\
\hline & & 78 & 52 & 57 & 53 \\
\hline
\end{tabular}

Based on table 1 it can be seen that the bid-ask spread is still above average. This is evidenced by the various industrial sectors, the consumer goods industry sector, the basic and chemical sector, the infrastructure, utilities and transportation sector, the financial sector, the mining sector, the agriculture sector, the property sector, the real estate and the building construction have bid-ask spread above the average of 175,87 , $94,114,86,153,104$, and 113 basis points. In 2014, the various industry sector, consumer goods industry sector, basic industry and chemical sector, trade, service, and investment sector have bid-ask spread above the average of 72,54 ,
72, 50, and 73 basis points. By 2015 the trade, services and investment sector, the mining sector, the agricultural sector have bid-ask spreads above the average of 61,83 , and 67 basis points. By 2016 the consumer goods industry sector, trade, services, and investment sectors, and the agricultural sector have bid-ask spreads above the average of 59,73 , and 75 basis points.

In the research that had been done before, there are inconsistent results of the study. Tri (2014: 256) stated that trading volume had a significant negative effect on bid-ask spread while Dananjoyo (2011: 47) stated that stock trading volume had a positive effect on bid-ask spread. 
Perdana and Kristanti (2014: 19) stated that the variance return had a significant positive effect on bid-ask spread while Dananjoyo (2011: 47) stated that the variance return had a negative effect on bid-ask spread. Surya (2016: 12) stated that market value had a positive effect on bid-ask spread while Fitriyah and Rahayu (2013: 18) stated that market value has negative effect on bid-ask spread. Raharjo (2014: 91) stated that the independence of the board of commissioners had a positive effect on bid-ask spread while Winoto (2017) stated that the independence of the board of commissioners significant positive effect on the bidask spread.

Based on the phenomenon, we are interested to examine about "The Effect of Trade Volume, Variance return, Market Value, and ROE to Bidask Spread on Companies in LQ45 Index Listed on Indonesia Stock Exchange Year 2013-2016".

\section{Problem Formulation}

Based on the above background, we formulated the following research issues:

1. Does trading volume influence to bid-ask spread?

2. Does the variance return influence to bid-ask spread?

3. Does the market value influence to bid-ask spread?

4. Does ROE influence to bid-ask spread?

5. Does the independence of the board of commissioners influence to bid-ask spread?

\section{Research Objectives}

The purpose of this study is to provide empirical evidence on whether or not:

1. the effect of trading volume on bid-ask spread,

2. the effect of variance return on bid-ask spread,

3. the effect of market value on bidask spread,

4. the effect of ROE on bid-ask spread,

5. the effect of the independence of the board of commissioners on bidask spread.

\section{LITERATURE REVIEW}

\section{LQ45 Index}

LQ45 was established to provide the market with an index that represents 45 of the most liquid stocks. Indonesian Stock Exchange in IDX Fack Book 2016 states that there are some of the factors for a stock to be included in the LQ45 Index:

1. The stocks should have been listed at the IDX for at least 3 months.

2 . The performance of the stock in the regular market, which includes its trading value, volume, and frequency of transactions.

3. The number of trading days in the regular market.

4. The stock's market the capitalization factors, the stocks selected for LQ45 index is also based on the financial condition and the prospect of growth of the companies.

5. Indonesian Stock Exchange regularly monitors the performance of the component stocks included in the calculation LQ45 index. Replacement stock will be conducted every 6 months, 
at the beginning of February and August.

\section{Bid-ask Spread}

Bid price is the highest price offered by the broker, while the ask price is the lowest price that the broker is willing to sell the stock (Ambarwati, 2008: 31). Conceptually bid-ask spread is the compensation given to the market maker for market maker's services (Ambarwati, 2008: 31). Stoll (1989: 115) states that the broker obtains compensation from the difference between the ask price and the bid price. The spread theory is a quoted spread theory (Stoll, 1989: 115). Quoted spreads should include three different types of costs faced by the dealer/broker:

1. Order processing cost

An order-processing component reflects the compensation for the dealer with respect to his expenditures for service provision. Such expenditures may arise from salaries for employees, costs of technical equipment or office rental, among other things (Rühl and Stein, 2015:2).
2. Inventory holding cost

The inventory component describes the influence of a dealer's inventory position in the relevant asset. Holding a specific inventory induces holding costs such as opportunity costs or costs of carrying the price risk (Rühl and Stein, 2015:2).

3. Adverse information cost

Order-driven markets involve the submission of public limit orders which supply liquidity to the market. The price dynamics are determined by all market participants instead of a single specialist or a few market makers. Thus, the adverse selection component in an order-driven market can be interpreted as private information that is impounded into prices through the order flow. A high level of information asymmetry could be driven by informed traders who have access to private information (Zhao et al, 2013:200).

Bid-ask spread is the difference between bid price with asks price (Tri, 2014: 251) formulated:

$$
\text { Bid ask spread }=\sum \frac{(\text { ask price }- \text { bid price })}{(\text { ask price }+ \text { bid price }) \times 0,5}: \mathrm{N}
$$

\section{Trading Volume}

Trading volume is defined as the number of shares traded on a particular day (Abdul and Nasuhi, 2000 in Ambarwati, 2008: 31). Stock trading volume is the number of shares traded daily (Jogiyanto, 2005: 48). Trading volume as the stock sheet traded on day (t) (Tri, 2014: 250).

$$
\mathrm{TVA}=\frac{\sum \text { stocks traded }}{\sum \text { stocks outstanding }}
$$




\section{Variance return}

Variance return shows the normal return variability caused by volatility (price fluctuation) of stock (Fitriyah and Rahayu, 2013: 4). The variance return is a measure of the total risk associated with the expected return of an equity firm's investment in year $t$ for a certain period (Arma, 2013: 207).

$$
\text { Variance return }\left(\sigma^{2}\right)=\frac{\sum_{\mathrm{i}=1}^{\mathrm{N}}[\mathrm{Xi}-\overline{\mathrm{X}}]^{2}}{\mathrm{~N}-1}
$$

\section{Market Value}

According to Atkins and Dyl (1997: 312) market value is the price of a stock that occurs in the stock market at a certain time. Larger firms' stocks are considered as investment grade and less risky than smaller firms' stocks, longer holding periods are expected for larger firms' stocks. Longer holding period will be impact on increasing bid-ask spread
(Chung and Wei, 2005:243). The more number of shares outstanding and the higher the stock price indicates the larger the size of the company. Market value can be measured by multiplying the number of shares outstanding with the closing stock price in the t-th period (Atkins and Dyl, 1997: 312).

$$
\text { Market value }=\sum_{t=1}^{N} \text { stock price } x \text { stock outstanding }
$$

\section{Return on Equity}

Return on Equity (ROE) is a ratio that measures the extent to which a company's ability to generate profits can be obtained by shareholders (Tandelilin, 2010: 372). The ratio of
ROE can be calculated by dividing net income by the amount of the company's equity (Kashmir, 2012: 204).

$$
\text { Return on Equity }=\frac{\text { Earning after taxes and interest }}{\text { Equity }}
$$

\section{The Independence of the Board of Commissioners}

The independence of the board of commissioners is responsible and authorized to oversee management action, and to provide advice to management if the independence of the board of commissioners deems it necessary to do so (KNKG, 2004). Fama and Jensen (1983) argue that outside directors will be more effective in monitoring while also providing more expert knowledge and added value to the company. 


$$
\text { Independence }=\frac{\text { number of independent commissioners }}{\text { the number of boards of commissioners }}
$$

\section{Theoretical Framework}

The effect of trading volume on bid-ask spread

The trade volume can be identified as having an effect on bid-ask spread. Trade volume describes the activity of the number of shares traded in the capital market. Small trading volumes tend to show investors' lack of confidence in a traded stock. In contrast, large trading volume indicates that the stock is in demand and actively traded by the investor so that the broker does not need to keep stocks too long, thereby it declines in stock ownership costs and it results in lower bid-ask spreads. Trading volume may be influenced by a number of factors such as the coverage of news coverage and the proportion of non-traded shares (the government usually controls a large proportion of restricted, non-traded shares (Chung and Wei, 2005:246). Volume is negatively related with the spread, with greater levels of volume resulting in reduced spread (Sabet \& Heaney, 2015:77). Therefore, trading volume has a negative effect on bid-ask spread. This is supported by research conducted by Tri (2014: 256).

1. The effect of variance return on bid-ask spread

The stock variance return represents the stock risk faced by the investors by the degree of uncertainty over expected returns. In every investment, investors will face the problem of uncertainty. Theoretically, the higher risk faced by the investors, investors will get a higher return. The risk seeker investors tend to invest in stocks that have a large variance return. The higher the risk due to stock price movements, the investor will keep the stock longer until the investor gets the expected return so that it results spread will be high. Therefore, the variance return has a positive effect on bid-ask spread. This is supported by research conducted by Dananjoyo (2011: 47).

2. The effect of market value on bidask spread

Market value is a reflection of the size of the company calculated by multiplying the number of shares outstanding with the stock market price (Fitriyah, 2013). Investors assume that large companies are able to produce good financial reports and information so that investors will expect to get returns from companies that result in wider spreads as investors tend to hold stocks longer (Kusumayanti, 2015). Therefore, market value has a positive influence on bid-ask spread. This is supported by research conducted by Surya (2016: 12). 
3. The effect of Return on Equity on bid-ask spread

High return on equity tends to increase investor interest in buying shares because they think the company has a good prospect of increasing profit. Companies that have good prospects then investors will tend to hold stocks longer by expected a high return. ROE has a positive effect on bidask spread. This is supported by research by Tengko et al.(2014: 674).

4. The effect of the independence of the board of commissioners on bidask spread

Based on the agency theory, to minimize problems arising from information asymmetry as well as to bridge the interests of owners and management, the independence of the board of commissioners is required to be able to provide information and conduct monitoring effectively (Raharjo, 2014: 44). A company with a larger the independence of the board of commissioners has less information asymmetry around earnings announcements or financial statements. This will have an impact on reducing the costs incurred by the broker to obtain information so it will make bid ask spread is small.

Based on the framework, we can describe the research paradigm as follows:

Figure 1. Research Paradigm

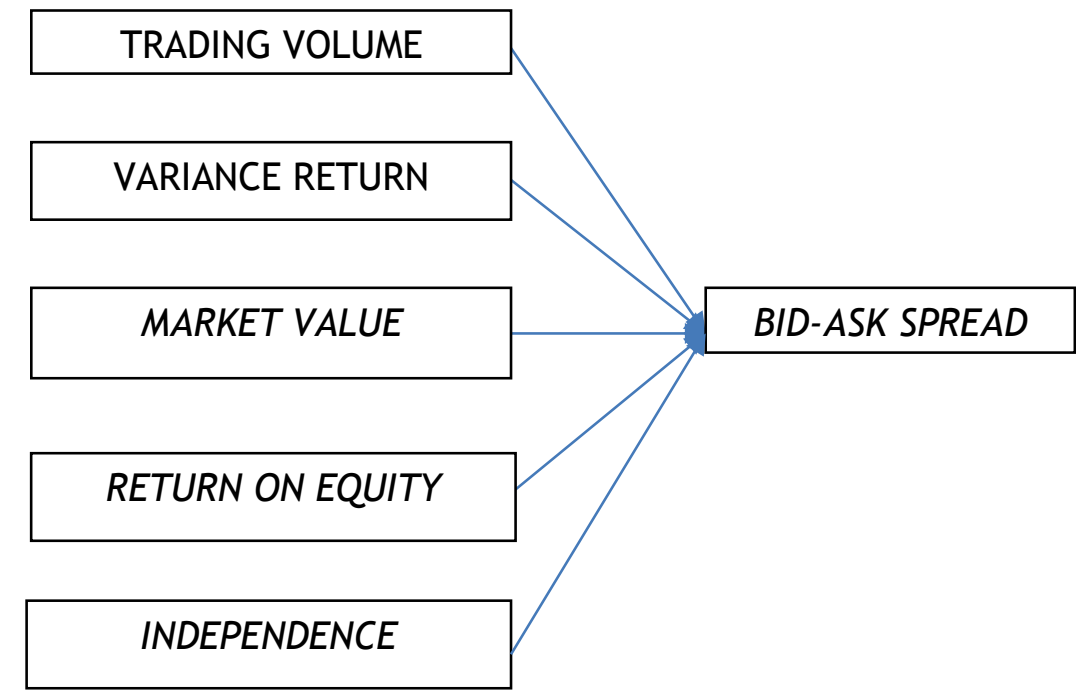

Based on the background and theoretical framework, it can be formulated research hypothesis as follows:

$\mathrm{H} 1$ : Trading volume has a negative effect on bid-ask spread
$\mathrm{H} 2$ : Variance return has a positive effect on bid-ask spread H3 : Market value has a positive effect on bid-ask spread

H4 : ROE has a positive effect on bid-ask spread 
H5 : the independence of the board of commissioners has has a negative effect on bid-ask spread.

\section{METHOD, DATA, AND ANALYSIS Method}

The method that will be used by us in this research is verification method and descriptive method. Verification method is a research method that aims to determine the causality relationship between variables through a hypothesis testing and through a statistical calculation so that the results obtained evidence that shows the hypothesis rejected or accepted (Sugiyono, 2013: 8). Besides the verification method in this research also use a descriptive method. Descriptive method is a method that serves to describe or provide an overview of the object under study through sample data or population as is without doing analysis and make conclusions that apply to the public (Sugiyono, 2015: 29).

\section{Operationalization of Variables}

1. Bid-ask spread $(\mathrm{Y})$ as a dependent variable

Bid-ask spread is the compensation given to the market maker for market maker's services (Ambarwati, 2008: 31).

Bid ask spread

$$
=\sum \frac{(\text { ask price }- \text { bid price })}{(\text { ask price }+ \text { bid price }) \times 0,5}: \mathrm{N}
$$

2. Trading volume $\left(X_{1}\right)$ as an independent variable
Trading volume is the number of shares traded daily (Jogiyanto, 2005: 48).

$$
\text { TVA }=\frac{\sum \text { stocks traded }}{\sum \text { stocks outstanding }}
$$

3. Variance return $\left(X_{2}\right)$ as an independent variable

$$
\begin{aligned}
& \text { Variance return }\left(\sigma^{2}\right) \\
& =\frac{\sum_{\mathrm{i}=1}^{\mathrm{N}}[\mathrm{Xi}-\overline{\mathrm{X}}]^{2}}{\mathrm{~N}-1}
\end{aligned}
$$

Variance return shows the normal return variability caused by volatility (price fluctuation) of stock (Fitriyah \& Rahayu, 2013)

4. Market value $\left(X_{3}\right)$ as an independent variable

Market value

$=\sum_{t=1}^{N}$ stock price $x$ stock outstanding

According to Atkins and Dyl (1997: 312) market value is the price of a stock that occurs in the stock market at a certain time.

5. Return on equity $\left(X_{4}\right)$ as an independent variable

Return on Equity (ROE) is a ratio that measures the extent to which a company's ability to generate profits can be obtained by shareholders (Tandelilin, 2010: 372).

Return on Equity

Earning after taxes and interest Equity 
6. The independence of the board of commissioners $\left(X_{5}\right)$ as an control variable

The independence of the board of commissioners is responsible and authorized to oversee management action, and to provide advice to management (KNKG, 2004).

Independence

$=\frac{\text { number of independent commissioners }}{\text { the number of boards of commissioners }}$

\section{Population and Sample}

The population in this research used a company that once entered into the LQ45 index multiplied by the period 2013-2016. So the calculation is as follows:

Population = company that ever entered into index LQ45 $x$ period 2013-2016

Population $=66$ companies $\times 4$ years

Population $=264$

So the population in this study is 264 financial statement data.

There are 28 companies used as samples. Sampling technique used in this research is purposive sampling technique. These 28 companies were selected as samples based on the following criteria: companies which for 8 consecutive periods or for 4 consecutive years enter into the LQ45 index.

\section{Data Collection Techniques}

The type of data is used in this research is quantitative data. Data in this research are the company's financial statements, stock price, bid price and offer price, number of outstanding shares, and trading volume of companies in LQ45 index for the period of 2013-2016 listed on the Indonesia Stock Exchange. The data used in this study is the annual data contained in the Indonesia Stock Exchange.

If it is viewed from the aspect of how to obtain, this research uses secondary data where data obtained in the form of finished, the results of the collection and processing of other parties obtained from the Indonesia Stock Exchange.

Data collection technique used in this research is an observation that is data collection by doing observation directly and indirectly to problem-related to research.

\section{Classic Assumption Test}

Classic assumption test use normality test, multicollinearity test, heteroscedasticity test, and autocorrelation test.

\section{Multiple Linear Regression Analysis}

The analytical method used is multiple linear regression analysis. In this study there are only four independent variables are trading volume, variance return, market value, and return on equity. The regression model that can be obtained in this analysis are:

$$
Y=a+b_{1} X_{1}+b_{2} X_{2}+b_{3} X_{3}+b_{4} X_{4}+€
$$

$\mathrm{Y}=$ Bid-ask Spread

$\mathrm{a}=$ Constanta

$\mathrm{X}_{1}=$ Trading Volume

$X_{2}=$ Variance Return

$\mathrm{X}_{3}=$ Market Value

$\mathrm{X}_{4} \quad=$ Return on Equity

$b_{1} b_{2} b_{3} b_{4}=$ regression coefficient 
$€=$ standard error

\section{Hypothesis Testing}

1. The t-test (partial)

t statistical test shows how far the influence of the explanatory variables / independent in explaining variation in the dependent variable (Ghozali, 2006:260).

2. Testing $F$ (simultaneous)
This test aims to determine the effect of independent variables together against the dependent variable to see significant value $F$. If the significance $F$ value less than 0.05 then the alternative hypothesis cannot be rejected or with $a=5 \%$ statistically independent variables affect the dependent variable together (Ghozali, 2006: 260).

\section{RESULT AND DISCUSSION Descriptive Analysis}

Table 2. Descriptive Analysis

\begin{tabular}{|l|c|c|c|c|c|}
\hline & $\mathrm{N}$ & Minimum & Maximum & Mean & Std. Deviation \\
\hline Trading_Volume & 112 &, 000172 &, 067706 &, 002416 &, 006594 \\
\hline Variance_Return & 112 & 8,86 & 477,23 & 109,98 & 93,92 \\
\hline Market_Value & 112 & 26.553 .054 .528 & 401.183 .985 .672$. & 88.503 .434 .878 .963 & 98.831 .212 .456414 \\
\hline ROE & 112 &, 10 & 32,78 & 15,484 & 6,694 \\
\hline Independence & 112 &, 00 &, 83 &, 2877 &, 23243 \\
\hline BAS & 112 &, 002 &, 016 &, 00641 &, 002985 \\
\hline
\end{tabular}

Based on the results of descriptive statistics in table 4.1, can know a description of each variable as follows:

\section{Trading Volume}

Based on table 4.1 shows that the stock trading volume of 112 data ranges from 0,000172 to 0,067706. Mean and standard deviation is 0,002416 and 0,006594 . The highest trading volume occurred in Lippo Karawaci Tbk. in 2013 of 0,067706 while the lowest trading volume occurred in PP (Persero) Tbk. in 2013 of 0.000172 .

\section{Variance Return}

Based on table 4.1 shows that variance return of 112 data ranged from 8,86 to 477,23 . Mean and standard deviation is 109,98 and 93,92 . The highest variance return occurred at PP London Sumatra Indonesia Tbk. in 2013 of 477.23 while the lowest variance variant occurred in Indofood Sukses Makmur Tbk. in 2014 of 8.86 .

\section{Market Value}

Based on table 4.1 shows that the market value of 112 data ranges from 26.553.054.528 to 401.183.985.672. The mean and standard deviation are 88.503.434.878.963 and 98.831.212.456414. The highest market value occurred in Telekomunikasi Indonesia (Persero) in 2016 of 401.183 .985 .672 while the lowest market value occurred in 
Lippo Karawaci Tbk. in 2013 of $26,553,054,528$.

\section{Return on Equity}

Based on table 4.1 shows that the magnitude of return on equity of 112 data ranged from 0,10 to 32,78 . The mean and standard deviation are 15,484 and 6,694. The highest return on equity occurred at Perusahaan Gas Negara (Persero) Tbk. in the year 2013 of 32,78 . Return on equity lowest occurred in Vale Indonesia Tbk. in 2013 of 0,10 .

5. The independence of the board of commissioners

Based on table 4.1 shows that the independence of the board of commissioners of 112 data ranged from 0,00 to 0,83 . The mean and standard deviation are 0,2877 and 0,23243. The highest return on equity occurred at Lippo
Karawaci Tbk. in the year 20132016 of 0,83 . Return on equity lowest occurred in Astra Agro Lestari Tbk., Adaro Energy Tbk., Astra International Tbk., Bank Rakyat Indonesia (Persero) Tbk., Bank Mandiri (Persero) Tbk., Charoen Pokphand Indonesia Tbk., Tambang Batubara Bukit Asam (Persero), Semen Indonesia (Persero) Tbk. in 2013-2016 of 0.00 .

6. Bid-ask Spread

Based on table 4.1 shows that the bid ask spread of 112 data ranges from 0.002 to 0.016 . Mean and standard deviation is 0.00641 and 0.002985. The highest bid-ask spread occurs at Alam Sutera Realty Tbk. in 2013 of 0.016 while the lowest bid-ask spread occurred in Vale Indonesia Tbk. 2013 of 0.002 .

\section{Verification Analysis}

1. Classic Assumption Test

a. Normality test

Table 3. Test of Normality of Kolmogorov-Smirnov Formula

One-Sample Kolmogorov-Smirnov Test

\begin{tabular}{|ll|r|}
\hline & & $\begin{array}{r}\text { Unstandardiz } \\
\text { ed Residual }\end{array}$ \\
\hline $\mathrm{N}$ & Mean & 112 \\
Normal Parameters & Stb. &, 0000000 \\
& Seviation &, 00270708 \\
Most Extreme & Absolute &, 113 \\
Differences & Positive &, 113 \\
Kolmogorov-Smirnov Z & Negative &,- 068 \\
Asymp. Sig. (2-tailed) & & 1,198 \\
\end{tabular}
a. Test distribution is Normal.
b. Calculated from data. 
Based on table 4.2 explains that the normality test using the formula kolmogorov-Smirnov test results obtained KSZ of 1.198 and Asymp. Sig of 0.114 is greater than 0.05 which means that the data is normally distributed.

b. Multicollinearity test

Table 4. Multicollinearity Test

\begin{tabular}{|l|l|r|r|}
\hline \multicolumn{2}{|l|}{ Model } & \multicolumn{2}{|c|}{ Collinearity Statistics } \\
\cline { 3 - 4 } \multicolumn{2}{|c|}{ Tolerance } & VIF \\
\hline \multirow{4}{*}{1} & (Constant) &, 942 & 1,061 \\
\cline { 2 - 4 } & Trading_Volume &, 789 & 1,268 \\
\cline { 2 - 4 } & Variance_Return &, 741 & 1,350 \\
\cline { 2 - 4 } & Market_Value &, 808 & 1,238 \\
\cline { 2 - 4 } & ROE &, 904 & 1,106 \\
\cline { 2 - 4 } & Independence & & \\
\hline \multicolumn{2}{|l}{ a. Dependent Variable: BAS }
\end{tabular}

Based on table 4.3 it can be explained that the tolerance value of trade volume, return variance, market value, and ROE is greater than 0.1 and the VIF value of trade volume tolerance, return variance, market value, and ROE is less than 10 so it can be concluded that a very strong correlation between each independent variable.

c. Heteroscedasticity Test

Table 5. Heteroscedasticity Test with Rank Spearman

\begin{tabular}{|l|c|c|}
\hline \multicolumn{1}{|c|}{ Variable } & Significance & Result \\
\hline Trading_Volume & 1,000 & no heteroscedasticity occurs \\
\hline Variance_Return & 1,000 & no heteroscedasticity occurs \\
\hline Market_Value & 1,000 & no heteroscedasticity occurs \\
\hline ROE & 1,000 & no heteroscedasticity occurs \\
\hline Independence & 1,000 & no heteroscedasticity occurs \\
\hline
\end{tabular}

d. Autocorrelation test

Table 6. Autocorrelation test with Durbin Watson

\begin{tabular}{|l|r|r|r|r|r|}
\hline \multicolumn{7}{|c|}{ Model Summary } \\
\hline 1 & $\mathrm{R}$ & R Square & $\begin{array}{c}\text { Adjusted R } \\
\text { Square }\end{array}$ & $\begin{array}{c}\text { Std. Error of } \\
\text { the Estimate }\end{array}$ & $\begin{array}{c}\text { Durbin- } \\
\text { Watson }\end{array}$ \\
\hline
\end{tabular}

a. Predictors: (Constant), Trading_Volume, Variance_Return, Market_Value, ROE, Independence

b. Dependent Variable: BAS 
Based on Table DW with $\mathrm{n}=112$ and the number of independent variables $=4$, the $\mathrm{dl}$ and du values are respectively 1.6187 and 1.7664 then
$\mathrm{du}<\mathrm{DW}<4-\mathrm{du}$ is $1.7664<\mathrm{DW}<2.2336$ DW $>1.7664$ so there is no autocorrelation.

\section{Multiple Linear Regression Analysis}

Table 7. Results of Multiple Linear Regression Analysis Test

Coefficients $^{\mathrm{a}}$

\begin{tabular}{|c|c|c|c|c|c|c|}
\hline \multirow{2}{*}{\multicolumn{2}{|c|}{ Model }} & \multicolumn{2}{|c|}{$\begin{array}{l}\text { Unstandardized } \\
\text { Coefficients }\end{array}$} & \multirow{2}{*}{\begin{tabular}{|c|}
$\begin{array}{c}\text { Standardized } \\
\text { Coefficients }\end{array}$ \\
Beta
\end{tabular}} & \multirow[t]{2}{*}{$\mathrm{t}$} & \multirow[t]{2}{*}{ Sig. } \\
\hline & & $B$ & $\begin{array}{l}\text { Std. } \\
\text { Error }\end{array}$ & & & \\
\hline \multirow{6}{*}{1} & (Constant) & ,004 & ,001 & & 4,898 & ,000 \\
\hline & Trading_Volume &,- 041 & ,041 &,- 090 &,- 993 & ,323 \\
\hline & Variance_Return & 0,000008 & ,000 & ,249 & 2,521 & ,013 \\
\hline & Market_Value & $1,000 \mathrm{E}-013$ &, 000 & ,240 & 2,358 & ,020 \\
\hline & ROE & ,000125 & ,000 & ,281 & 2,904 & ,004 \\
\hline & Independence & 0,000145 & ,001 & ,011 & ,122 & ,903 \\
\hline
\end{tabular}

a. Dependent Variable: BAS

Based on the above table can be formulated regression model as follows:

$Y=0.004-0.041$ trading_volume+
0,000008 variance_return $+1,000 \mathrm{E}-$ 013 market_value $+9,512 \mathrm{E}+$ $0,000125 \quad$ ROE $+\quad 0,000145$ Independence.

Table 8. Coefficient of Determination

\begin{tabular}{|l|r|r|r|r|}
\multicolumn{7}{|c}{ Model Summary } \\
\hline Model & R & R Square & $\begin{array}{c}\text { Adjusted R } \\
\text { Square }\end{array}$ & $\begin{array}{r}\text { Std. Error of } \\
\text { the Estimate }\end{array}$ \\
\hline 1 &, $421^{\mathrm{a}}$ &, 177 &, 147 &, 002757 \\
\hline
\end{tabular}

a. Predictors: (Constant), Trading_Volume, Variance_Return, Market_Value, ROE

b. Dependent Variable: BAS

From result of determinant coefficient analysis, obtained $R$ value equal to 0.421 . This shows that trading volume, variance return, market value, ROE, and independence together influence the bid-ask spread of $17.7 \%$ and the remaining $82.3 \%$ is influenced by other variables not included in this research. 


\section{Hypothesis Testing}

1. The t-test (partial)

Table 9. $\mathrm{t}$ test

\begin{tabular}{|l|c|c|c|c|}
\hline \multicolumn{1}{|c|}{ Variable } & $\mathrm{t}_{\text {count }}$ & $\mathrm{t}_{\text {table }}$ & Sig. & Alpha \\
\hline Trading_Volume & $-0,993$ & -1.981372 & 0,323 & 0,05 \\
\hline Variance_Return & 2,521 & 1.981372 & 0,013 & 0,05 \\
\hline Market_Value & 2,358 & 1.981372 & 0,020 & 0,05 \\
\hline ROE & 2,904 & 1.981372 & 0,004 & 0,05 \\
\hline Independence & 0,122 & 1.981372 &, 903 & 0,05 \\
\hline
\end{tabular}

a. The effect of trading volume on bid-ask spread

Based on Table 4.8, it is known that trading volume has value $-\mathrm{t}$ count $>-\mathrm{t}$ table and sig value> alpha value, it can be said that the trading volume effect is not significant to bid-ask spread. Since the effect is not significant then it can be assumed that trading volume has no effect on bid-ask spread. Hence the hypothesis that there is a negative effect of trading volume on bid-ask spread is rejected $\left(\mathrm{H}_{\mathrm{a}}\right.$ is rejected and $\mathrm{H}_{0}$ is accepted).

b. The effect of variance return on bid-ask spread

Based on table 4.8 , it is known that variance return has a value of $t$ count $>t$ table and sig value <alpha value, then it can be said that the variance return influence significantly to bid-ask spread. Thus the hypothesis which states that there is a positive influence of return on bid-ask spread is accepted $\left(\mathrm{H}_{\mathrm{a}}\right.$ is accepted and $\mathrm{H}_{0}$ rejected).

c. The effect of market value on bidask spread

Based on table 4.8 , it is known that the market value variable has a value of $t$ count $>t$ table and sig value <alpha value, it can be said that market value influences significantly to bid-ask spread. Thus the hypothesis which states that there is a positive effect of market value on the bidask spread is accepted $\left(\mathrm{H}_{\mathrm{a}}\right.$ is accepted and $\mathrm{H}_{0}$ rejected).

d. The effect of Return on Equity on bid-ask spread

Based on table $4.8, \mathrm{t}$ is known that the ROE has a value of $\mathrm{t}$ count $>\mathrm{t}$ table and sig value <alpha value, then it can be said that ROE influences significantly to bid-ask spread. Thus the hypothesis which states that there is a positive effect of ROE on the bid-ask spread is accepted $\left(\mathrm{H}_{\mathrm{a}}\right.$ is accepted and $\mathrm{H}_{0}$ rejected).

e. The effect of The independence of the board of commissioners on bidask spread

Based on table $4.8, \mathrm{t}$ is known that the independence of the board of commissioners has a value of $t$ count $>t$ table and sig value $<$ alpha value, then it can be said that the independence of the board of commissioners effect is not significant to bid-ask spread. Since the effect is not significant 
then it can be assumed that the independence of the board of commissioners has no effect on bid-ask spread. Hence the hypothesis that there is a negative effect of trading volume on bidask spread is rejected $\left(\mathrm{H}_{\mathrm{a}}\right.$ is rejected and $\mathrm{H}_{0}$ is accepted).

\section{Testing $F$ (simultaneous)}

Table 10. $\mathrm{F}$ test

ANOVA $^{a}$

\begin{tabular}{|c|c|c|c|c|c|}
\hline Model & $\begin{array}{l}\text { Sum of } \\
\text { Squares }\end{array}$ & $\overline{\mathrm{Df}}$ & $\begin{array}{l}\text { Mean } \\
\text { Square }\end{array}$ & $\mathrm{F}$ & Sig. \\
\hline Regression &, 000 & 5 & \multirow{3}{*}{$\begin{array}{l}, 000 \\
, 000\end{array}$} & \multirow[t]{3}{*}{$\overline{4,574}$} & \multirow[t]{3}{*}{, $001^{b}$} \\
\hline Residual & ,001 & 106 & & & \\
\hline Total & ,001 & 111 & & & \\
\hline
\end{tabular}

a. Dependent Variable: BAS

b. Predictors: (Constant), Trading_Volume, Variance_Return, Market_Value, ROE, Independence

Based on table $4.8 \mathrm{t}$ is known that the variable ROE has a value of $F$ count $>F_{\text {table }}$ and sig value $<$ alpha value, then it can be said that ROE influences significantly to bid-ask spread. Thus trading volume, variance return, market value, $\mathrm{ROE}$, and the independence of the board of commissioners have positive effect on bid ask spread.

\section{Discussion}

a. The effect of trading volume on bid-ask spread

Trading volume has no significant effect on bid-ask spread because trading volume traded at that time is not supported by large trading frequency as well. This means that high trading volume is not formed by the active trading process of investors. Thus high trading volume cannot indicate that the stock is in demand by investors because there is a possibility that high trading volume is a result of massive purchases from certain parties to increase the liquidity of the stock. Based on these conditions, it can be concluded that the bid-ask spread of stocks listed on LQ45 index is not significantly affected by the trading volume. The results of this research are consistent with the results of research conducted by Napitupulu (2013) which states that stock trading volume has no significant effect on bid-ask spread.

b. The effect of variance return on bid-ask spread

Variance return is a stock risk that can affect the size of the bid-ask spread.. A high variance return indicates that the stock has a high degree of uncertainty over the expected return of the stock. Increased risk of stock causes the dealer or broker to try to overcome it by determining a larger spread. So that high risk of 
stock can be covered by a large price spread as compensation from the uncertainty of the return of the stock. Variant return positively affects bid-ask spread. This is in accordance with research conducted by Ambarwati (2008), and Dananjoyo (2011).

c. The effect of market value on bidask spread

Investors assume that large companies are able to produce reports and financial information well so that investors will expect to get a return from the company so that investors tend to hold stocks longer resulting in widening spreads. Therefore, market value positively affects bid-ask spread. This is in accordance with research conducted by Surya (2016).

d. The effect of Return on Equity on bid-ask spread

High ROE tends to increase investor interest in stocks because it considers the company has a good prospect of increasing profit. With high ROE, investors will hold their shares longer by expecting high returns. Investors will sell their stocks when the investors have a high return. When investors hold the stock longer, it will make a high spread. Therefore, ROE has a positive effect on bid-ask spread. This is in accordance with Tengko et al. (2014).

e. The effect of the independence of the board of commissioners on bidask spread
The results of this study contradict the basic theory, as it should be the existence of the independence of the board of commissioners supports the principle of deep responsibility the implementation of Corporate Governance, which requires companies to provide better information as a form of accountability to stakeholders. This indicates that independent commissioners have not been effective in carrying out its responsibilities overseeing the quality of financial reporting in order to reduce information asymmetry. This is in accordance with Meilani (2009).

\section{CONCLUSION}

This study aims to determine the effect of trading volume, variance return, market value, and return on equity on bid-ask spreads on the good prospect of increasing profit companies listed in the LQ45 index period 2013-2016. The results of hypothesis testing used multiple linear regression analysis showed that:

1. Trading volume has a insignificant positive effect on bid-ask spread.

2. Variance return has a significant positive effect on bid-ask spread.

3. Market value has a significant positive effect on bid-ask spread.

4. Return on Equity has a significant positive effect on bid-ask spread.

5. The independence of the board of commissioners has a insignificant positive effect on bid-ask spread. 


\section{IMPLICATION/LIMITATION SUGGESTION}

This research has several limitations as follows:

1. This study uses only five independent variables are trading volume, variance return, market value, and return on equity, the independence of the board of commissioners.

2. This research is only limited to companies listed in the LQ45 index so that the conclusions obtained cannot be generalized to all sectors of the company.

\section{REFERENCE}

Ambarwati, S. D. A. (2008). Pengaruh Return Saham, Volume Perdagangan Saham Dan Varian Return Saham Terhadap Bid-ask Spread Saham Pada Perusahaan Manufaktur Yang Tergabung Dalam Indeks LQ 45 Periode Tahun 2003-2005. Jurnal Siasat Bisnis, 12(1).

Arma, V. Y. (2013). Faktor Penentu Holding Period Saham LQ 45 di Bursa Efek Indonesia. Journal of Business \& Banking, 3(2), 201212.

Atkins, A., \& Dyl, E. (1997). Transaction costs and holding periods for common stocks. Journal of Finance, 52, 309- 325.

Bursa Efek Indonesia. (2016). Retrieved from http://www.idx.co.id.

Chung and Wei. 2005. The relationship between bid-ask spreads and holding periods: The case of Chinese A and B shares. Global Finance Journal, 15, 239249.
Dananjoyo, T. R. (2011). Pengaruh return Saham, Volume Perdagangan Saham Dan Varian Return Saham Terhadap Bid-Ask Spread Saham Di Bursa Efek Indonesia (Periode 2006-2010). E-journal Manajemen Universitas Atma Jaya Yogyakarta, 13-01.

Fahmi, I. (2015). Pengantar Manajemen Keuangan Cetakan Keempat. Bandung: C.V Alfabeta.

Fitriyah, F., \& Rahayu, Y. S. (2013). Variabel-Variabel Penentu Holding Periods Saham Syari'ah Di Indonesia. El Muhasaba: Jurnal Akuntansi, 4(1).

George, T. J., \& Longstaff, F. A. (1993). Bid-ask spreads and trading activity in the S\&P 100 index options market. Journal of Financial and Quantitative Analysis, 28(3), 381-397.

Ghozali, I. (2006). Aplikasi Analisis Multivariate dengan Program SPSS. Semarang: Badan Penerbit Universitas Diponegoro.

Hagströmer, B., Henricsson, R., \& Nordén, L. L. (2016). Components of the Bid-Ask Spread and Variance: A Unified Approach. Journal of Futures Markets, 36(6), 545-563.

Jogiyanto. (2005). Pasar Efisien secara Keputusan. Edisi Pertama, PT Gramedia Pustaka Utama, Jakarta.

Kasmir. (2015). Analisa Laporan Keuangan. Jakarta: Rajawali Pers.

Kusumayanti, D. (2015). Pengaruh Bid-Ask Spread, Market Value, Variance Of Return Dan Dividend Payout Ratio Terhadap Holding Period Saham Pada Perusahaan 
Manufaktur Yang Terdaftar Di BEI. Periode 2011-2013. (Undergraduate Thesis Universitas Negeri Yogyakarta, Yogyakarta).

Megginson, W.L. (1997). Corporate Finance Theory, Addison-Wesley Education Publisher, Inc.

Meilani. (2009). Pengaruh mekanisme corporate governance terhadap asimetri Informasi (Studi Empiris Pada Perusahaan Yang Terdaftar Di Bursa Efek Indonesia Periode 2004 - 2007). (Thesis Universitas Negeri Semarang, Semarang).

Napitupulu, V., \& Syahyunan, S. (2013). Pengaruh Return Saham, Volume Perdagangan dan Volatilitas Harga Saham terhadap Bid-Ask Spread pada Perusahaan yang Melakukan Stock Split di Bursa Efek Indonesia. Jurnal Media Informasi Manajemen, 1(2).

Perdana, M. A., \& Kristanti, F. T. (2014). Pengaruh Varian Return, Harga Saham, Volume Perdagangan, Earning Per Share Terhadap Bid-ask Spread Saham Syariah (Studi Empiris Pada Perusahaan Yang Terdaftar Pada Jakarta Islamic Index Tahun 2010-2012). eProceedings of Management, 1(3).

Raharjo. (2014). Pengaruh Ukuran Dewan Komisaris, Direksi, Komisaris Independen, Struktur Kepemilikan, Dan Indeks Corporate Governance Terhadap Asimetri Informasi. Jurnal Ekonomi Dan Bisnis.

Rühl, T. R., \& Stein, M. 2015. The impact of ECB macroannouncements on bid-ask spreads of European blue chips.
Journal of Empirical Finance, 31, 54-71.

Sabet, A. H., \& Heaney, R. (2015). Bid-ask spread, information asymmetry and acquisition of oil and gas assets. Journal of International Financial Markets, Institutions and Money, 37, 7784.

Saham Ok. (2016). Retrieved from http://www.sahamok.com.

Stoll, H. R. (1989). Inferring the Components of the Bid-ask Spread:Theory and Empirical Tests. The Journal of Finance, 44(1), 115-134.

Sugiyono. (2015). Statistika untuk Penelitian. Bandung: ALFABETA

Surya, K. (2016). Pengaruh Harga Saham, Volume Perdagangan, Market Value dan Varian Return terhadap Bid-ask Spread (Studi Empiris Pada Perusahaan yang Terdaftar di Daftar Efek Syariah). (Undergraduate Thesis Universitas Muhammadiyah Yogyakarta, Yogyakarta).

Tandelilin, E. (2010). Portofolio dan Investasi Teori dan Aplikasi. Edisi pertama. Yogyakarta : Kanisius.

Tengko, et al. (2014). Determinan Penentu Bid-Ask Spread Pada Trend Bullish Market Perbankan Yang Go Public Di BEI. Jurnal Riset Ekonomi, Manajemen, Bisnis Dan Akuntansi, 2(1).

Tri, C.Y. (2014). Volume Perdagangan dan Return Saham dalam Hubungannya dengan Bid-Ask Spread pada Perusahaan Go Public. Syariah Paper Proceeding Seminar Nasional dan Call for Paper. (pp. 241-260). Universitas Muhammadiyah Surakarta Publication, Surakarta. 
INDONESIAN JOURNAL OF BUSINESS AND ECONOMICS Vol. 1 Issue 1, June 2018

Winoto, R. (2017). Pengaruh Tata Kelola Perusahaan, Kualitas Auditor dan Earning Per Share Terhadap Bid-Ask Spread. Junal Akuntansi Bisnis, 16(1).
Printed ISSN 2621-6167, e-ISSN 2621-4466 https://journal.uniku.ac.id/index.php/ijbe

Zhao et al.. 2013. Short sales, margin purchases and bid-ask spreads. Pacific-Basin Finance Journal, 24, 199-220. 